\title{
FORMS OF NITROGEN FERTILIZER APPLICATION IN Panicum maximum
}

\author{
FORMAS DE APLICAÇÃO DE ADUBO NITROGENADO EM Panicum maximum
}

\author{
Marilize Bittencourtt CALDAS'; Jéssica Pereira DINIZ1; Andrisley Joaquim da SILVA²; \\ Simone Pereira da Silva BAIO'; ${ }^{1}$ Monica Cristina Rezende Zuffo BORGES; \\ Kenio Batista NOGUEIRA ${ }^{\mathbf{~}}$; Cassiano Garcia ROQUE' ${ }^{\mathbf{1}}$ Paulo Eduardo TEODORO ${ }^{1 *}$ \\ 1. Universidade Federal de Mato Grosso do Sul (UFMS), Chapadão do Sul, MS, Brasil; 2. Centro Universitário de Mineiros, \\ Mineiros, GO, Brasil; 3. Universidade Federal do Vale do São Francisco (UNIVESF), Petrolina, PE, Brasil. \\ *eduteodoro@hotmail.com
}

\begin{abstract}
Nitrogen is one of the most important nutrients for increasing the yield and quality of forages. This study aimed to evaluate the effect of the different forms of application, spread on the total area using urea fertilizer and foliar using liquid urea, aiming at evaluating the yield and qualitative traits of Panicum maximum cv. Mombaça, at different times of the year. The experimental design was completely randomized blocks in subdivided plots, with three blocks, four treatments, and three collections. The treatments were applied in March 2015 and consisted of the following treatments: 1-control; 2-urea; 3-liquid urea; 4-urea + liquid urea; 5-urea + micronutrients; 6-urea $+\mathrm{N}$ liquid; 7-urea $+\mathrm{N}$ liquid + micronutrients; 8-control. Samples were collected in May, October, and December 2015. Crude protein (CP) dry matter (DM), mineral matter (MM), and acid detergent fiber (ADF) were evaluated. Results revealed that nitrogen was determinant in improving the yield and forage quality. Treatments with urea spread on total area resulted in increased dry matter production. For the crude protein, the source and the application form are not decisive. Collection time with higher rainfall positively affected the dry matter production, crude protein, and ADF, while urea spread on total area showed the best cost-benefit due to the good results of yield and quality.
\end{abstract}

KEYWORDS: Forage productivity. Crude protein. Acid detergent fiber.

\section{INTRODUCTION}

The interest in the genus Panicum has increased due to the production potential and ease of establishment, characteristics of adaptation, rusticity, and good dry matter production. These facts makes it one of the most important forages for the production of beef and dairy cattle in tropical and subtropical climate regions of Brazil. Mombaça grass, a cultivar belonging to the species Panicum maximum, is of great relevance for the Brazilian cattle owing to its high phytomass production, good acceptability, and good nutritive value (TORRES et al., 2016).

Nitrogen is the primary nutrient in forage productivity because it is linked to the metabolic pathway of the formation of proteins, chloroplasts, and other compounds that participate actively in photosynthesis (PRADO, 2008). Hence, this nutrient becomes responsible for the plant development, such as height and the formation of tiller and leaves. It also promotes linear plant development, and fertilization rates positively affect the production (FERNANDES, 2011).

The leaf area index and the tiller population density increase linearly with nitrogen fertilization in pastures (REZENDE, 2008). This element can reach the soil in several ways. The most common and natural way of reaching the soil is through the decomposition of organic compounds. However, it can also happen by the biological fixation provided by specialized microorganisms. Rarely, nitrogen fixation will occur by electric discharges. Inorganic fertilization is the the most used form of nitrogen fixation (PRADO, 2008).

Urea is the most commonly used nitrogen fertilizer. It can be applied to pastures by incorporating it into the soil before the establishment of the forage or spread on the total area on the already established forage. However, this type of nitrogen fertilization leads to waste, which can occur through volatilization, erosion, and leaching.

Nitrate is available in the soil solution, especially in the topsoil owing to its negative charge and for not being adsorbed by soil colloids. Therefore, when it is not immobilized by the soil microbiota nor absorbed by plants, it tends to be lost due to its high mobility (PRIMAVESI et al., 2006). Erosion consists of the disintegration and transport of soil particles by water or wind, resulting from the impact on the physical properties of the soil, which can degrade the environment (BERTONI; LOMBARDI NETO, 2010) due to the soil structure. As nitrate is present in the topsoil, when erosion 
occurs, nitrate and other nutrients, as well as mineral salts, are lost and led to lower reliefs.

According to Pietroski et al. (2015), foliar fertilization may be an alternative in pastures, resulting in increased forage production, green color index, and $\mathrm{N}$ accumulation, proving to be an essential complementary practice to nitrogen fertilization via soil.

The nitrogen fertilization recommendation for the establishment and maintenance in Cerrado is 40 to $50 \mathrm{~kg} \mathrm{ha}^{-1}$ at the establishment stage, and 40 $\mathrm{kg} \mathrm{ha}^{-1}$ year $^{-1}$ at the maintenance stage (WERNER et al.,1996; CANTARUTTI et al., 1999; VILELA et al., 2002; adapted from MACEDO 2004). This study aimed to evaluate the yield and qualitative traits of Panicum maximaum cv Mombaça forages under different fertilization methods, using urea fertilizer and liquid urea at three collection times.

\section{MATERIAL AND METHODS}

The experiment was conducted in the Lombeiro Farm, municipality of Paraíso das Águas, State of Mato Grosso do Sul (18 57'57.80” S, $52^{\circ} 55^{\prime} 55.80^{\prime}$ 'W and altitude of $\left.699 \mathrm{~m}\right)$. The area is occupied by a pasture of Panicum maximum cv. Mombaça, already established three years ago, and previously cultivated with soybean for two years. The soil of the experimental area was classified as Quartzarenic Neosol (Embrapa, 2013). Table 1 shows the soil chemical properties determined before installing the experiment. The climate, according to the Köppen's classification is tropical humid (Aw), with well-defined seasons, rainy in the summer and dry in the winter. The average annual temperature varies from $13^{\circ} \mathrm{C}$ to $28^{\circ} \mathrm{C}$; the average annual rainfall is $1,850 \mathrm{~mm}$; and the average annual relative humidity is $64.8 \%$ (CASTRO et al., 2012).

Table 1. Soil chemical properties before installing the experiment at the 0-0.20 m layer. Paraíso das Águas-MS,

\begin{tabular}{|c|c|c|c|c|c|c|c|c|c|}
\hline O.M & $\mathrm{pH}$ & $P$ & $\mathrm{~K}$ & $\mathrm{Ca}$ & $\mathrm{Mg}$ & $\mathrm{H}+\mathrm{Al}$ & SB & CEC & \\
\hline $\mathrm{g} \mathrm{dm}^{-3}$ & $\mathrm{CaCl}_{2}$ & $\mathrm{mg} \mathrm{dm^{3 }}$ & & ---- & $----c$ & $m^{-3}$ & --- & & $\%$ \\
\hline 20 & 6.1 & 20 & 0.03 & 2.8 & 0.5 & 1.3 & 3.3 & 4.6 & 72 \\
\hline
\end{tabular}

The experiment was installed on March 15, 2015 , in a completely randomized block design with three blocks, four treatments, and three collection times. The experimental plot consisted of 624.00 $\mathrm{m}^{2}$. For the experimental treatments, urea in the solid and liquid form was used (Table 2), following the manufacturer's recommendations.

Table 2. Treatments and application forms used.

\begin{tabular}{lccc}
\hline Treatments/Application forms & Urea (kg.ha & Liquid Urea (ml) & Micronutrients (ml) \\
\hline 1- Urea & 200.00 & 0 & 0 \\
2- N liquid + micronutrients & 0 & 62.4 & 62.4 \\
3- N liquid & 0 & 62.4 & 0 \\
4- Micronutrients & 0 & 0 & 62.4 \\
5- Urea + micronutrients & 200.00 & 0 & 62.4 \\
6- Urea + N liquid & 200.00 & 62.4 & 0 \\
7- Urea + N liquid + micronutrients & 200.00 & 62.4 & 62.4 \\
8- Control & 0 & 0 & 0 \\
\hline
\end{tabular}

According to the manufacturer, liquid urea is a compound containing phosphoric acid solution, carboxylic acids, anionic surfactant additives, emulsifiers, preservatives, amino acids, 1\% EDTA chelating agents, and water. It is a fertilizer with $18 \% \mathrm{~N}$ and $2 \% \mathrm{P} 2 \mathrm{O} 5$. Therefore, $\mathrm{P}$ was balanced in all other procedures, following a recommendation of
$1000 \mathrm{ml} /$ ha. For each picket, $62.4 \mathrm{ml}$ were applied via leaf.

The solid urea used, according to the manufacturer, has $45 \%$ water-soluble nitrogen $(\mathrm{N})$ and high hygroscopic capacity. With the recommendation of $200 \mathrm{~kg}$ per hectare, , $12.48 \mathrm{~kg}$ per picket were applied. Liquid urea was applied using a tractor and sprayer, by diluting one liter of 
the product (liquid urea) into 150 liters of water, and 9.42 liters of the mixture were distributed per picket.

During the experiment, three plant material collections were carried out. The first one occurred on the sixteenth day after applying the product, comprising from May 18 to 25, 2015 (dry season). The second collection occurred from September 28 to October 5, 2015 (rainy season), and the third and last collection occurred from November 30 to December 7, 2015 (rainy season). A lot of 20 Holstein cows grazed once every 24 days on each picket.

Each collection consisted of three samples per plot, making a composite sample, totaling four samples per block, and 12 samples collected. Samples were collected using a square of $0.25 \mathrm{~m}^{2}$ $(0.5 \mathrm{~m} \times 0.5 \mathrm{~m})$ randomly placed on the plot, simulating the grazing, and collecting leaves at 0.40 $\mathrm{m}$ from the soil.

After collection, samples were weighed in natura and placed in a forced air-circulation oven at 60-65 ${ }^{\circ} \mathrm{C}$ for 72 hours. After drying, samples were weighed again for the dry matter calculation. Subsequently, samples were ground individually in a knife-type mill, identified, and stored in plastic bags for the bromatological analysis.

The analyses carried out were crude protein (CP) (SILVA, 1998), according to the Kjeldahl methodology, followed by the analysis of dry matter (DM), mineral matter (MM), by the Weende method, and Acid Detergent Fiber (ADF), according to the Van Soest (1994) methodology. For each cut, analysis of variance was performed, and the contrast between Fertilization vs Control was estimated. Subsequently, the data were submitted to the Tukey test and the multivariate analysis of clustering and principal components. The analyses were performed with Rbio software (BHERING, 2017).

\section{RESULTS AND DISCUSSION}

Analysis of variance for the variables evaluated in each cut is contained in Table 3. The fertilization forms influenced the dry mass in all cuts. The contrast between fertilization forms and control was significant for DM and crude protein (CP) in all cuts; for mineral material (MM), it was significant in cut 1 .

Table 3. Summary of the analysis of variance for the variable dry matter (DM), crude protein (CP), acid detergent fiber (ADF), and mineral material (MM) evaluated in Panicum maximum cv. Mombaça, under different forms of nitrogen application, during three cuts.

\begin{tabular}{|c|c|c|c|c|c|}
\hline Sources of variation & Degrees of freedom & DM & $\mathrm{CP}$ & $\mathrm{ADF}$ & $\mathrm{MM}$ \\
\hline & \multicolumn{5}{|c|}{ Cut 1} \\
\hline Blocks & 2 & $11.94^{\mathrm{ns}}$ & $0.32^{\mathrm{ns}}$ & $1.27^{\mathrm{ns}}$ & $1.74^{\mathrm{ns}}$ \\
\hline Fertilization $(\mathrm{F})$ & 6 & $87.17 *$ & $2.57^{\mathrm{ns}}$ & $7.24^{\mathrm{ns}}$ & $0.48^{\mathrm{ns}}$ \\
\hline F vs Control & 1 & $315.82 *$ & $13.02 *$ & $7.27^{\mathrm{ns}}$ & $7.52 *$ \\
\hline Error & 14 & 19.86 & 1.30 & 2.86 & 0.30 \\
\hline CV (\%) & --- & 8.95 & 8.49 & 5.30 & 7.19 \\
\hline \multirow[t]{2}{*}{ Overall mean } & --- & 12.75 & 12.92 & 31.94 & 7.61 \\
\hline & \multicolumn{5}{|c|}{ Cut 2} \\
\hline Blocks & 2 & $53.44 *$ & $8.44^{*}$ & $10.38^{*}$ & $1.95^{\mathrm{ns}}$ \\
\hline Fertilization $(\mathrm{F})$ & 6 & $114.02 *$ & $0.28^{\mathrm{ns}}$ & $1.68^{\mathrm{ns}}$ & $0.36^{\mathrm{ns}}$ \\
\hline F vs Control & 1 & $225.93 *$ & $7.73 *$ & $2.73^{\text {ns }}$ & $0.47^{\mathrm{ns}}$ \\
\hline Error & 14 & 12.31 & 1.02 & 1.77 & 0.46 \\
\hline CV (\%) & --- & 11.84 & 8.26 & 4.44 & 8.66 \\
\hline \multirow[t]{2}{*}{ Overall mean } & --- & 29.63 & 12.22 & 29.98 & 7.84 \\
\hline & \multicolumn{5}{|c|}{ Cut 3} \\
\hline Blocks & 2 & $10.19^{\mathrm{ns}}$ & $12.22 *$ & $1.85^{*}$ & $3.99^{\mathrm{ns}}$ \\
\hline Fertilization (F) & 6 & $86.60 *$ & $1.17^{\mathrm{ns}}$ & $0.49^{\mathrm{ns}}$ & $8.78^{\text {ns }}$ \\
\hline F vs Control & 1 & $360.16^{*}$ & $23.23^{*}$ & $0.11^{\mathrm{ns}}$ & $1.93^{\mathrm{ns}}$ \\
\hline Error & 14 & 11.95 & 0.80 & $0.27^{\mathrm{ns}}$ & $11.48^{\mathrm{ns}}$ \\
\hline CV (\%) & --- & 9.73 & 6.06 & 6.80 & 10.05 \\
\hline Overall mean & --- & 35.52 & 14.76 & 7.59 & 33.70 \\
\hline
\end{tabular}

${ }^{\mathrm{ns}}$ and $*$ : not significant and significant at $5 \%$ probability by the $\mathrm{F}$ test, respectively.

Table 4 shows that the use of different forms of nitrogen fertilizer provided the highest means of DM and $\mathrm{CP}$, regardless of the cut, besides the higher $\mathrm{MM}$ in cut 1 . Given that fertilization is one of the practices that most influence pasture production cost, the form of fertilization that 
provides greater dry mass production must be

identified.

Table 4. Contrast of means between fertilization forms and the control for dry matter (DM) and crude protein (CP), evaluated in cuts 1,2 and 3, and mineral material (MM), evaluated in the cut 1 .

\begin{tabular}{lccccccc}
\hline \multirow{2}{*}{ Treatment } & \multicolumn{3}{c}{ DM kg ha ${ }^{-1}$} & \multicolumn{2}{c}{ CP $(\%)$} & \multicolumn{2}{c}{ MM (\%) } \\
& Cut 1 & Cut 2 & Cut 3 & Cut 1 & Cut 2 & Cut 3 & Cut 1 \\
Fertilization & $3.586 \mathrm{a}$ & $3.086 \mathrm{a}$ & $3.698 \mathrm{a}$ & $13.02 \mathrm{a}$ & $12.44 \mathrm{a}$ & $15.13 \mathrm{a}$ & $7.82 \mathrm{a}$ \\
Control & $2.490 \mathrm{~b}$ & $2.099 \mathrm{~b}$ & $2.527 \mathrm{~b}$ & $10.80 \mathrm{~b}$ & $10.72 \mathrm{~b}$ & $12.16 \mathrm{~b}$ & $6.13 \mathrm{~b}$ \\
\hline
\end{tabular}

Means of crude protein content ranged from $12.16 \%$ (treatment without nitrogen) to $15.13 \%$ (nitrogen treatment) for the third cut, reflecting an increase of $20 \%$ (Table 2). The higher CP content in cut 3 in relation to the other cuts can be explained due to the higher rainfall volume in this period (Figure 1) since the increase in water depth increases crude protein content of Panicum maximum cv. Mombaça (FILHO MOCHEL et al., 2016).

In all forms of fertilization, $\mathrm{CP}$ contents were higher than $7 \%$ (Table 2). According to Van Soest (1994), a higher CP content is required to meet the protein requirements of the animal's organism since CP levels lower than $7 \%$ reduces the digestion system of the animal owing to inadequate levels of nitrogen for the rumen microorganismsand hence reducing the dry mass digestibility and intake. Based on this assertion, itMombaça grass satisfies the minimum requirements of ruminants with any of the fertilization forms used, increasing the performance and weight gain by the animals (DIAS et al., 1998).

Table 5 contains the Tukey multiple means comparison of the different fertilization forms for $\mathrm{DM}$ production. Treatment urea $+\mathrm{N}$ liquid + micronutrients provided the highest means in all cuts. However, it should be noted that the use of urea in the conventional form or accompanied by micronutrients or liquid $\mathrm{N}$ showed no difference in the most complete treatment, regardless of the cut.

Table 5. Dry matter $\left(\mathrm{kg} \mathrm{ha}^{-1}\right)$ of Panicum maximum $\mathrm{cv}$. Mombaça under different forms of fertilization in three cuts.

\begin{tabular}{lcccc}
\hline Treatments/Application forms & Cut 1 & Cut 2 & Cut 3 & Accumulation \\
\hline 1- Urea & $3.524 \mathrm{ab}$ & $3.534 \mathrm{a}$ & $4.243 \mathrm{a}$ & $11.301 \mathrm{a}$ \\
2- N liquid + micronutrients & $3.415 \mathrm{ab}$ & $2.554 \mathrm{bc}$ & $2.954 \mathrm{~b}$ & $8.923 \mathrm{~b}$ \\
3- N liquid & $2.975 \mathrm{~b}$ & $2.477 \mathrm{c}$ & $3.161 \mathrm{ab}$ & $8.613 \mathrm{~b}$ \\
4- Micronutrients & $2.977 \mathrm{~b}$ & $2.461 \mathrm{c}$ & $3.534 \mathrm{ab}$ & $8.972 \mathrm{~b}$ \\
5- Urea + micronutrients & $4.077 \mathrm{ab}$ & $3.463 \mathrm{ab}$ & $3.948 \mathrm{ab}$ & $11.488 \mathrm{a}$ \\
6- Urea + N liquid & $3.708 \mathrm{ab}$ & $3.083 \mathrm{ab}$ & $3.644 \mathrm{ab}$ & $10.435 \mathrm{ab}$ \\
7- Urea + N liquid + micronutrients & $4.429 \mathrm{a}$ & $4.031 \mathrm{a}$ & $4.405 \mathrm{a}$ & $12.865 \mathrm{a}$ \\
\hline
\end{tabular}

The increase in dry matter (DM) production due to nitrogen fertilization can be explained by the fact that nitrogen accelerates growth, tillering, leaf production, and, consequently, the expansion of shoots (FREITAS et al., 2005; PATÊS et al., 2007). $\mathrm{N}$ acts directly in the improvement of the photosynthesis efficiency and in the promotion of the carbon priority redistribution for the shoot formation (SANTOS et al., 2008). Similar results were found by Filho Mochel et al. (2016), who assessed Mombaça grass and obtained higher DM production with nitrogen fertilization. The authors justify that because nitrogen fertilization promote plant growth, the photosynthetic area is increased, consequently increasing dry mass production.
The reduction in the DM production using liquid $\mathrm{N}$ could have possibly occurred due to volatilization losses. This fact decreases the nitrogen use efficiency, which may have decreased the amount of $\mathrm{N}$ available to the forage plants. The occurrence of rainfall and high temperatures (Figure 1) after the foliar liquid nitrogen application probably caused $\mathrm{N}$ loss by volatilization. According to Carvalho and Saraiva (1987), relative urea efficiency is highly variable, and this occurs owing to $\mathrm{N}$ losses due to climatic conditions during the application.. High temperatures may cause the drying of the applied solution and toxicity on the leaf surface, while high air humidity causes reduced leaf absorption due to the lower contact of the product with the leaf surface (ROSOLEM, 2002). 
Cluster analysis was performed to facilitate the identification of the best treatments, based on all variables(Figure 1). Treatments with urea were clustered in Group I, which contains the highest means of DM and CP. The other forms of fertilization, including control (8), were clustered in Group II. This result confirms the importance of nitrogen for the forage nutritional quality since these are the most critical forage attributes.
No differences were observed among treatments containing urea. Therefore, the use if urea is recommended for being more affordable, at $200 \mathrm{~kg} \mathrm{ha}^{-1}$, for maintenance purposes and as a guarantee of good crude protein contents and dry mass production.

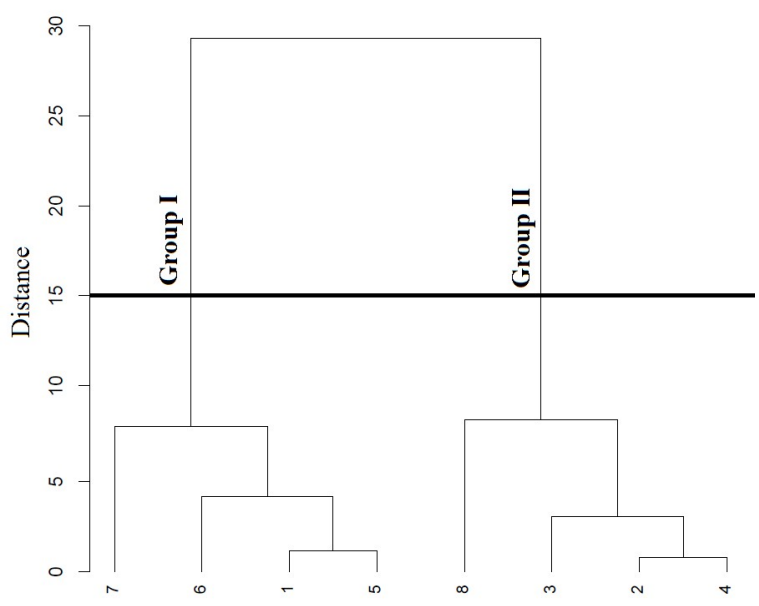

Figure 1. Clustering among treatments based on Euclidean distance and Ward's hierarchical algorithm.

Principal component analysis (PCoA) was performed to verify what variables contributed the most to the discrimination of treatments (Figure 2). The use of PCoA is effective when the first two principal components can retain more than $80 \%$ of the total data variability and, like cluster analysis, the treatments were arranged into two primary groups. Group 1 contains the treatments with urea, where the variables DM and CP were the ones that contributed the most to its formation. This information has practical relevance for the producers because the amount of dry mass and their quality (CP) are the main variables that influence the animal weight gain.

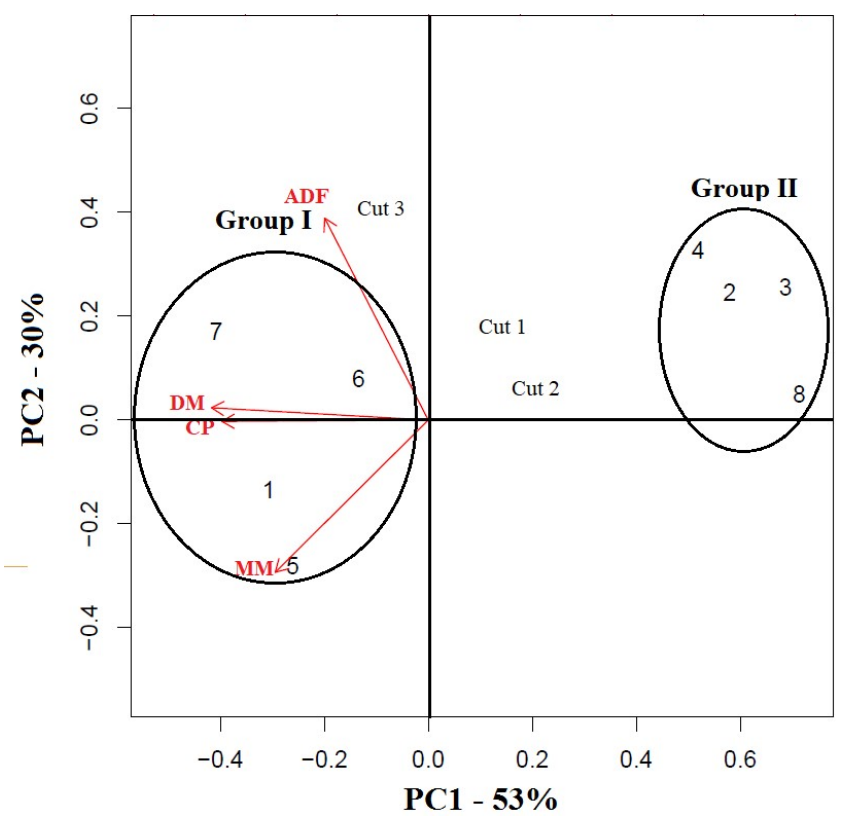

Figure 2. Principal component analysis among treatments based on three cuts. 
Forms of nitrogen...

\section{ACKNOWLEDGEMENTS}

The authors thank CAPES for granting the scholarship the second author of this manuscript.

CONCLUSIONS
CALDAS, M. B. et al.

Nitrogen was determinant in improving the availability and quality of forage.

The treatments with urea spread on the total area obtained the highest dry matter production.

The collection time affected the dry matter production, crude protein, and ADF sincehighrainfall periods obtained better results.

RESUMO: O nitrogênio é um dos nutrientes mais importantes para o aumento da produtividade e qualidade das forrageiras. Este trabalho teve como objetivo avaliar o efeito das diferentes formas de aplicações, sendo elas à lanço (utilizando ureia fertilizante) e foliar (utilizando ureia líquida), a fim de avaliar as características produtivas e qualitativas da forrageira Panicum maximum cv. Mombaça, em diferentes épocas do ano. O delineamento experimental foi o de blocos inteiramente casualizados em parcelas subdivididas, com oito tratamentos e três coletas. Os tratamentos foram aplicados em março de 2015 e eram constituídos pelo tratamento 1: controle, tratamento 2: ureia, tratamento 3: ureia líquida, 4: ureia + ureia líquida; 5-ureia + micronutrientes; 6-ureia $+\mathrm{N}$ líquido; 7- ureia $+\mathrm{N}$ líquido + micronutrients; 8-controle. Foram realizadas coletas em maio/2015, outubro/2015 e dezembro/2015. Foram avaliadas proteína bruta (PB), massa de matéria seca (MMS), matéria mineral (MM) e fibra em detergente ácido (FDA). Os resultados revelaram que o nitrogênio foi determinante na melhora da produtividade e qualidade da forrageira. Os tratamentos com ureia aplicada a lanço resultaram na maior produção de massa de matéria seca. Para a proteína bruta, a fonte e o formato de aplicação não foram decisivos. A época de coleta com maior pluviosidade afetou positivamente a produção de massa de matéria seca, proteína bruta e o FDA da forrageira; e a ureia aplicada a lanço apresentou o melhor custo-benefício atrelado aos bons resultados de produtividade e qualidade.

PALAVRAS-CHAVE: Produtividade de forragem. Proteína bruta. Fibra em detergente ácido.

\section{REFERENCES}

BERTONI, J.; LOMBARDI NETO, F. Conservação do solo. 7. ed. São Paulo: Ícone, 2010.

BHERING, L.L. Rbio: A Tool For Biometric And Statistical Analysis Using The R Platform. Crop Breeding and Applied Biotechnology, Viçosa, v. 17, p. 187-190, 2017. https://doi.org/10.1590/198470332017v17n2s29.

CARVALHO, M.M.; SARAIVA, O. F. Resposta do Capim Gordura (Melinnis minutiflora Beau.) a aplicação de nitrogênio em regime de cortes. Revista Brasileira Zootecnia, Viçosa, v. 16, n. 5, p. 442-454, 1987.

CASTRO, M.A.; CUNHA, F.F.; LIMA, S.F.; PAIVA NETO, V.B.; LEITE, A.P.; MAGALHÃES, F.F.; CRUZ, G.H.M. Atributos físico-hídricos do solo ocupado com pastagem degradada e floresta nativa no Cerrado SulMato-Grossense. Brazilian Geographical Journal, Ituiutaba, v. 3, n. 2, p. 498- 512, 2012.

DIAS, P. F.; ROCHA, G. P.; OLIVEIRA, A. I. G.; PINTO, J. C.; ROCHA FILHO, R. R.; SOUTO, S. M. Produtividade e qualidade de gramíneas forrageiras tropicais sob adubação nitrogenada no final do período das águas. Pesquisa Agropecuária Brasileira, Brasília, v. 33, n.7, p. 1191-1197, 1998.

FAGUNDES, J.L.; FONSECA, D.M.; MORAIS, C.; MORAIS, R.V.; VITOR, C.M.T.; REIS, G. C.; CASAGRANDE, D.R; SANTOS. M.E.R. Índice de área foliar, densidade de perfilhos e acumulo de forragem em pastagem de Capim-Brachiaria adubada com nitrogênio. Boletim de Indústria Animal, Nova Odessa, v.62, n.2, p.125-133, 2, 2005.

FERNANDES, J.C. Fontes e doses de nitrogênio na adubação do capim-Mombaça em cerrado de baixa altitude. 2011. 51 f. Dissertação (Mestrado em Agronomia - Sistemas de Produção), Faculdade de EngenhariaUnesp- Campus de Ilha Solteira, Ilha Solteira, SP. 
FILHO MOCHEL. W. J. E.; CARNEIRO, M. S. de S.; ANDRADE, A. C.; PEREIRA. E.S.; ANDRADE. A.P.; CANDIDO. M. J. da D. S.; MAGALHÃES, J. A.; RODRIGUES. B.H.N.; SANTOS, F.J. de S.; COSTA, N. L.; Produtividade e composição bromatológica de Panicum maximum cv. Mombaça sob irrigação e adubação azotada. Revista de Ciências Agrárias, Lisboa, v.39, n.1, 2016. https://doi.org/10.19084/RCA14154

FREITAS, K.R.; ROSA, B.; RUGGIERO, J.A.; NASCIMENTO, J.L.; HEINEMAM, A.B.; FERREIRA, P.H.; MACEDO, R. Avaliação do capim-Mombaça (Panicum maximum Jacq.) submetido a diferentes doses de nitrogênio. Acta Scientiarum Agronomy. Maringá, v. 27, no. 1, p. 83-89, 2005.

https://doi.org/10.4025/actasciagron.v27i1.2154

MACEDO, M.C.M Análise comparativa de recomendações de adubação em pastagens. In: Simpósio sobre o Manejo da Pastagem, 21., Piracicaba, 2004. Fertilidade do solo para pastagens produtivas. Piracicaba, Fealq, 2004. p. 317-355.

PATÊS, N. M. S.; PIRES, A. J. V.; SILVA, C. C. F. SANTOS, L. C.; CARVALHO, G. G. P.; FREIRE, M. A. L. Características morfogênicas e estruturais do capim-tanzânia submetido a doses de fósforo e nitrogênio. Revista Brasileira de Zootecnia, Viçosa, v. 36, n. 6, p. 1736-1741, 2007. https://doi.org/10.1590/S151635982007000800005

PIETROSKI, M.; OLIVEIRA, R.; CAIONE, G. Adubação foliar de nitrogênio em capim mombaça Panicum maximum cv. Mombaça. Revista de Agricultura Neotropical, Cassilândia, v. 2, n. 3, p. 49-53, 2015. https://doi.org/10.32404/rean.v2i3.684

PRADO, Renato de Melo. Manual de nutrição de plantas forrageiras. Jaboticabal: Funep, 2008. 500 p.

PRIMAVESI, O.; PRIMAVESI, A.C.; CORRÊA, L.A.; SILVA, A. G.; CANTARELLA, H. Lixiviação de nitrato em pastagem de coastcross adubada com nitrogênio. Revista Brasileira de Zootecnia, Viçosa, v. 35, $\mathrm{n}$. 3, p. 683-690, 2006. https://doi.org/10.1590/S1516-35982006000300008

REZENDE. N. Gramíneas forrageiras sob diferentes doses de adubação nitrogenada no Sudoeste Goiano. 2008. 26 f. Dissertação (Mestrado em Agronomia - Produção Vegetal), Universidade Federal de Goiás, Jataí. 2008.

ROSOLEM, C. A. Recomendação e aplicação de nutrientes via foliar. Lavras: UFLA/FAEPE, 2002. 98 p.

SANTOS, E. M; ZANINE, A. M; FERREIRA, D. J; OLIVEIRA, J. S; PEREIRA, O. G. Composição química do feno de capim-tanzânia (Panicum maximum) tratado com hidróxido de sódio. Arquivo de Ciência Veterinária e Zoologia, v.11, n.1, p.41-46, 2008.

SILVA, D. J. Análise de alimentos: métodos químicos e biológicos. Viçosa: Ed. UFV, 1998. 166 p.

TORRES, F. E.; TEODORO, P. E.; BENITES, S. B.; OLIVEIRA, E. P.; CORREA, C. C. G.; SILVA, F. A. Number of cuts for estimating forage productivity in P. maximum. Bioscience Journal (Online), Uberlândia, v. 32, p. 172-178, 2016. https://doi.org/10.14393/BJ-v32n1a2016-29307

VAN SOEST, P. J. Nutritional ecology of the ruminant. 2. ed. Ithaca: Cornell University, 1994.476 p. 